УДК 336.73

JEL Classification: Q18, F65

КОСТИРКО Л. А. ${ }^{1}$, СОЛОМАТІНА Т. В. ${ }^{2}$

\title{
ФІНАНСОВИЙ ПОТЕНЦАЛ КРЕДИТНИХ СПІЛОК У СИСТЕМІ РОЗВИТКУ МАЛИХ ФОРМ АГРОБІЗНЕСУ
}

\author{
DOI: $10.32620 /$ cher.2020.1.08
}

Постановка проблеми. Стаття присвячена аналізу тенденцій розвитку кредитних спілок та обгрунтуванню науково-практичних рекомендацій щодо зростання фінансового потенціалу кредитних спілок у системі розвитку малих форм агробізнесу. Mema cmammi- розробка теоретичних основ і практичних рекомендацій щодо зростання фінансового потенціалу кредитних спілок у системі розвитку малих форм господарювання в аграрній сфері. Об'єкт дослідження - фінансовий потенціал кредитних спілок. Методи, використані в дослідженні: узагальнення, порівняння, логічнозмістовний, наукового пізнання, індукції, аналізу. Гіпотеза дослідження: аналітична оцінка тенденцій розвитку кредитних спілок для визначення можливостей залучення коштів для малих форм агробізнесу. Виклад основного матеріалу. Проаналізовано динаміку кількості кредитних спілок, чисельності охоплюваних ними осіб, обсягів капіталу, кредитно-депозитного портфеля, ризиків діяльності, як загалом, так і в рамках всеукраїнської асоціації. Надано критичну оцінку правового статусу і пруденційного регулювання, визначено їх вплив на розкриття фінансового потенціалу кредитних спілок та їх переваги для малих форм агробізнесу: представництво в регіонах із розвинутим сільськогосподарським виробництвом, територіальна доступність, можливість для особистих підсобних $\mathrm{i}$ фермерських господарств отримати невеликі за обсягом суми кредиту на тривалий термін. Оригінальність та практичне значення полягає у розробці рекомендацій щодо підтримки кредитними спілками діяльності малих форм господарювання в аграрній сфері. Висновки дослідження: Кредитні спілки (КС) мають значні конкурентні переваги перед банками на рівні споживчого кредитування та кредитування сільських товаровиробників. Тому, залучення вільних коштів кредитних спілок відігратиме важливу роль у розвитку малих форм господарювання в аграрній сфері.

\section{Ключові слова:}

фінансовий потенціал, кредитні спілки, малі форми, агробізнес, кредитно-депозитний портфель, кредитування, регулювання.

\section{THE FINANCIAL POTENTIAL OF CREDIT UNION IN THE SYSTEM OF DEVELOPMENT OF SMALL FORMS OF AGRIBUSINESS}

Formulation of problem. The article is focused on the analysis of trends of development of credit unions and the basis for scientific and practical recommendations regarding increasing the financial potential of credit unions in system of development of small forms of agrarian business. The aim of research is the development of theoretical aspects and practical recommendations regarding increasing the financial potential of credit unions in system of development of small forms of governance in agrarian area. The object of the research is the financial potential of credit unions. Methods, used in research: generalization, comparison, logical and informative, scientific knowledge, induction, analysis. The hypothesis of the research: analytical evaluation of development trends of credit unions for identification of the feasibility of fund-raising for small forms agrarian business. The statement of basic materials. The dynamics of quantity of credit unions, the number of persons included by them, the amount of capital, loan and deposit portfolio, risks of activity is analysed as a whole and in the frames of all-Ukrainian association. The critical estimation of le-

${ }^{1}$ Костирко Лідія Андріївна, д-р екон. наук, професор, завідувач кафедри «Фінанси та банківська справа», Східноукраїнский національний університет імені Володимира Даля, м. Сєвєродонецьк, Україна.

Kostyrko Lydia, Doctor of Economic Sciences, Head of Finances and Banking Department Volodymyr Dahl East Ukrainian National University, Severodonetsk, Ukraine.

ORCID ID: 0000-0002-3447-2343

e-mail: lidiyakostyrko@gmail.com

${ }^{2}$ Соломатіна Тетяна Василівна, канд. екон. наук, доцент кафедри «Фінанси та банківська справа», Східноукраїнский національний університет імені Володимира Даля, м. Сєвєродонецьк, Україна.

Solomatina Tetyana, Associate Professor, Ph.D. in Economic, Associate Professor of Finances and Banking Department Volodymyr Dahl East Ukrainian National University, Severodonetsk, Ukraine.

ORCID ID: 0000-0002-1949-3277

e-mail: t.solomatina@i.ua 
gal status and prudential regulation is provided, their influence on the disclosure of financial potential of credit unions and their advantages for small forms of agrarian business as representation in regions with developed agricultural production, territorial accessibility, the opportunity of to give modest amouts of credit sums for a long term for household plots and farms is determined. The originality and practical significance of the research is the development of recommendations regarding support for small forms of governance in agrarian area by credit unions. Conclusions and perspectives of further researches. Credit unions (CU) have significant competitive advantages over banks at the level of consumer loans and credit for rural commodity producers. Therefore, free fund-raising of credit unions will play an important role in the development of small forms of governance in agrarian area.

Key words:

financial potential, credit unions, small forms, agrarian business, loan and deposit portfolio, credit, regulation.

\section{ФИНАНСОВЫЙ ПОТЕНЦИАЛ КРЕДИТНЫХ СОЮЗОВ В СИС ТЕМЕ РАЗВИТИЯ МАЛЫХ ФОРМ АГРОБИЗНЕСА}

Постановка проблемы. Статьи посвящена анализу тенденций развития кредитных союзов и обоснованию научно-практических рекомендаций касательно роста финансового потенциала кредитных союзов в системе развития малых форм агробизнеса. Цель статьи - разработка теоретических основ и практических рекомендаций касательно роста финансового потенциала кредитных союзов в системе развития малых форм хозяйствования в аграрной сфере. Объект исследования - финансовый потенциал кредитных союзов. Meтоды, использованные в исследовании: обобщение, сравнение, логически-содержательный, научного познания, индукции, анализа. Гипотеза исследования: аналитическая оценка тенденций развития кредитных союзов для определения возможностей привлечения средств для малых форм агробизнеса. Изложение основного материала. Проанализирована динамика количества кредитных союзов, численности охватываемых ими лиц, объемов капитала, кредитно-депозитного портфеля, рисков деятельности, как в целом, так и в рамках всеукраинской ассоциации. Дана критическая оценка правового статуса и пруденциального регулирования, определено их влияние на раскрытие финансового потенциала кредитных союзов и их преимущества для малых форм агробизнеса: представительство в регионах с развитым сельскохозяйственным производством, территориальная доступность, возможность для личных подсобных и фермерских хозяйств получить небольшие по объему суммы кредита на длительный срок. Оригинальность $u$ практическое значение состоит в разработке рекомендаций по поддержке кредитными союзами деятельности малых форм хозяйствования в аграрной сфере. Выводы исследования: кредитные союзы (КС) имеют значительные конкурентные преимущества перед банками на уровне потребительского кредитования и кредитования сельских товаропроизводителей. Поэтому привлечения свободных средств кредитных союзов будет играть важную роль в развитии малых форм хозяйствования в аграрной сфере.

\section{Ключевые слова:}

финансовый потенциал, кредитные союзы, малые формы, агробизнес, кредитно-депозитный портфель, кредитование, регулирование.

Постановка проблеми. Кредитна система складає важливу частину будь-якої розвинутої сучасної економіки та відіграє суттєву роль в іiі функціонуванні. Основними елементами кредитного ринку є банківські установи і небанківські фінансові установи. Важливе місце в кредитній системі країн світу посідає фінансово-кредитна кооперація, представлена кооперативними банками, ощадно-позичковими та кредитними кооперативами i товариствами, кредитними спілками тощо.

В умовах банківсько-орієнтованої фінансової системи України на частку банківської сфери припадає більш ніж 80\% фінансових трансакцій. Банківські установи висувають високі вимоги до кредитування суб'єктів агроекономіки: банк землі більше 500 га, сума кредиту - більше 100 тис. грн., вартість застави має перевищувати суму кредиту у 2-3 раза [1, с. 104]. Кредитні спілки (КС) мають досить значні конкурентні переваги перед банками на рівні споживчого кредитування та кредитування сільських товаровиробників, проте їх фінансовий потенціал в Україні на сьогодні розкрито недостатньо.

Аналіз останніх досліджень i публікацій. Проблеми функціонування кредитних спілок як джерела фінансування підприємств аграрного сектора економіки 
знаходяться в центрі уваги багатьох учених. У працях Добровольської О. В., Катан Л. І., Кібенко К. С., Клименко В. І., Косюги В. В., Крот Л. М., Левандовської А. В., Орлова О. В. досліджується економічна сутність кредитних спілок як особливої форми сільськогосподарської кредитної кооперації, їх конкурентоспроможність, особливості кредитнодепозитного портфеля, ризики функціонування, засади пруденційного регулювання. Високо оцінюючи науковий доробок зазначених авторів, слід визнати недостатню увагу до галузевих аспектів фінансування кредитними спілками національної економіки.

Мета статті полягає у розробці теоретичних основ і практичних рекомендацій щодо зростання фінансового потенціалу кредитних спілок у системі розвитку малих форм господарювання в аграрній сфері.

Виклад основного матеріалу дослідження. «Кредитна спілка - це неприбуткова організація, заснована фізичними особами, професійними спілками, їх об'єднаннями на кооперативних засадах 3 метою задоволення потреб іiі членів у взаємному кредитуванні та наданні фінансових послуг за рахунок об'єднаних грошових внесків членів кредитної спілки» [2]. Таким чином, кредитні спілки в Україні визнані неприбутковою організацією, а не кооперативом, що стримує їх розвиток в системі кредитної кооперації. Оскільки поняття «кооперативні засади» чітко не прописані, то за своїм статусом кредитні спілки тяжіють до фінансових установ. Кредитна спілка поєднує в собі функції, які притаманні, з одного боку, установам банків, а 3 іншого - фінансовим небанківським інституціям.

Кредитні спілки залучають кошти та надають кредити тільки своїм членам. Їх перевагами є: задоволення потреб сільськогосподарських виробників в дрібному кредиті; близькість знаходження кредитора до позичальника; підвищення матеріальної зацікавленості членів кооперативу в результатах своєї праці; підвищення соціального становища вкладників; зменшення витрат кредиторів та позичальників, а також неплатежів за боргами кооперативу; створення за ініціативою самих селян; здійснення діяльності не тільки $з$ кредитуванням, а й з обслуговування інших потреб селян; розширення первинних сільських кредитних кооперативів до регіональних кредитних організацій [3; 4]. Актив- ну діяльність зі створення кредитних спілок, які обслуговують особисті підсобні та фермерські господарства, проводять підприємства споживчої кооперації та сільськогосподарські обслуговуючі кооперативи. Діяльність кредитних спілок сприяє збільшенню обсягів сільськогосподарського виробництва, особливо в тваринництві, яке здійснюється в основному в рамках дрібно-товарних господарств.

Перспективним напрямком діяльності кредитних спілок на селі є фінансування розвитку зеленого туризму в частині поліпшення громадського та приватного житлового фонду, місцевої інфраструктури доріг, утримання та будівництва мереж водопостачання і каналізації, відновлюваних джерел енергіі; забезпечення зайнятості селян, які надають послуги 3 перевезення, харчування, розміщення туристів, пристосовуючи власні будинки під міжнародні стандарти тощо [5, с. 89].

Система кредитної кооперації України має розгалужену територіальну інфраструктуру, через іï осередки фінансуються суб' єкти господарювання різних галузей національної економіки, але близько третини позичальників проживає у сільській місцевості і представлена особистими селянськими i фермерськими господарствами. Сільські кредитні спілки надають фінансові послуги сільським мешканцям із невеликими доходами та невисоким рівнем життя, дрібним підприємцям, а також сільськогосподарським товаровиробникам, доступ яких до ресурсів банківської системи є ускладненим [6, с. 83]. Як специфічна форма організації фінансової взаємодопомоги, кредитна спілка об'єднує громадян за професійною, територіальною чи іншою ознакою, яка вказується в статуті і $€$ визначальною при прийнятті ії нових членів.

Станом на 01.10.2019 року у Державному реєстрі фінансових установ зареєстровано 348 кредитних спілок, у т.ч. у територіальному розділі найбільша їх кількість припадає на м. Київ та Київську область - 39 $(11,2 \%)$; друге місце поділяють Луганська область - $31(8,9 \%)$ та Донецька область - 28 $(8 \%)$; третє місце - Харківська область - 22 $(6,3 \%)$ та Львівська область - 20 (5,7\%) [7]. Станом на 01.10.2019 року учасниками Всеукраїнської асоціації кредитних спілок (ВАКС) є 76 кредитних спілок (КС) [8], в т.ч. 38 iз них $(50 \%)$ знаходяться у Західному регіоні, 18 КС (24\%) у Східному регіоні, 17 
КС (22\%) у Центральному регіоні і лише 3 КС (4\%) у Південному регіоні.
У табл. 1 наведено показники діяльності кредитних спілок України, у т.ч. об’єднаних у ВАКС.

Т а бли ц я 1

Показники розвитку кредитних спілок в Україні

\begin{tabular}{|c|c|c|c|c|c|c|}
\hline \multirow[b]{2}{*}{ Показник } & \multirow[b]{2}{*}{2016} & \multirow[b]{2}{*}{2017} & \multirow[b]{2}{*}{2018} & \multirow[b]{2}{*}{2019} & \multicolumn{2}{|c|}{$2019 / 2016$} \\
\hline & & & & & приріст & $\begin{array}{c}\text { темп } \\
\text { приросту }\end{array}$ \\
\hline \multicolumn{7}{|c|}{ Всього } \\
\hline Кредитні спілки, од. & 462 & 378 & 358 & 348 & -114 & $-24,68$ \\
\hline \multicolumn{7}{|l|}{ млн грн. } \\
\hline Вклади членів кредитної спілки & 831,8 & 937,0 & 1045,7 & 1149,1 & 317,3 & 38,15 \\
\hline Активи & 2032,5 & 2169,8 & 2218,4 & 2441,1 & 408,6 & 20,10 \\
\hline Кредитний портфель & 1799,5 & 1902,3 & 2018,0 & 2267,3 & 467,8 & 26,00 \\
\hline Капітал & 1044,4 & 1062,5 & 977,1 & 1106,1 & 61,7 & 5,91 \\
\hline Частка прострочених кредитів, \% & 20,5 & 18,2 & 17,5 & 17,0 & $-3,5$ & $-17,07$ \\
\hline $\begin{array}{l}\text { Члени кредитних спілок, тис. осіб, у } \\
\text { т. ч. }\end{array}$ & 642,9 & 564,1 & 479,0 & 465,2 & $-177,7$ & $-27,64$ \\
\hline вкладники & 41,1 & 21,7 & 17,6 & 20,3 & $-20,8$ & $-50,61$ \\
\hline позичальники & 148,6 & 134,3 & 148,6 & 119,9 & $-28,7$ & $-19,31$ \\
\hline \multicolumn{7}{|l|}{ Питома вага, \% } \\
\hline - вкладники & 6,4 & 3,8 & 3,7 & 4,4 & -2 & $-31,25$ \\
\hline - позичальники & 23,1 & 23,8 & 31,0 & 25,8 & 2,7 & 11,69 \\
\hline \multicolumn{7}{|c|}{ Всеукраїнська академія кредитних спілок (ВАКС) } \\
\hline Кредитні спілки & 86 & 82 & 79 & 76 & -10 & $-11,63$ \\
\hline \multicolumn{7}{|l|}{ млн грн. } \\
\hline Вклади членів кредитної спілки & 348,4 & 411,6 & 476,0 & 526,5 & 178,1 & 51,12 \\
\hline Активи & 691,7 & 783,8 & 866,1 & 953,0 & 261,3 & 37,78 \\
\hline Кредитний портфель & 633,0 & 706,9 & 803,2 & 895,9 & 262,9 & 41,53 \\
\hline Капітал & 295,4 & 317,6 & 320,9 & 344,8 & 49,4 & 16,72 \\
\hline Частка прострочених кредитів & 16,6 & 15,4 & 13,9 & 12,4 & $-4,2$ & $-25,30$ \\
\hline $\begin{array}{l}\text { Члени кредитних спілок, тис. осіб, у } \\
\text { т. ч. }\end{array}$ & 288,7 & 268,5 & 234,8 & 216,4 & $-72,3$ & $-25,04$ \\
\hline вкладники & 14,2 & 13,9 & 62,8 & 12,8 & $-1,4$ & $-9,86$ \\
\hline позичальники & 73,4 & 68,5 & 10,8 & 60,4 & -13 & $-17,71$ \\
\hline \multicolumn{7}{|l|}{ Питома вага, \% } \\
\hline - вкладники & 4,9 & 5,2 & 26,7 & 5,9 & 1 & 20,41 \\
\hline - позичальники & 25,4 & 25,5 & 4,6 & 27,9 & 2,5 & 9,84 \\
\hline \multicolumn{7}{|c|}{ Питома вага ВАКС } \\
\hline Кредитні спілки & 18,6 & 21,7 & 22,1 & 21,8 & 3,2 & 17,20 \\
\hline Члени кредитних спілок & 44,9 & 47,6 & 49,0 & 46,5 & 1,6 & 3,56 \\
\hline Активи & 34,0 & 36,1 & 39,0 & 39,0 & 5 & 14,71 \\
\hline Капітал & 28,3 & 29,9 & 32,8 & 31,2 & 2,9 & 10,25 \\
\hline
\end{tabular}

Джерело: побудовано авторами за даними [7; 8]

У 2003 р. було створено Всеукраїнську асоціацію кредитних спілок (ВАКС) з метою представництва, захисту інтересів своїх членів та обслуговування їх на регіональному рівні. ВАКС об'єднує найбільш потужні установи: іiі питома вага у кількості кредитних спілок становить у 2019 р. $21,8 \%$, у кількості членів кредитних спілок - 46,5\%, в активах і капіталі - відповідно 39,0\% і 31,2\%.
Протягом 2016-2019 рр. кількість кредитних спілок скоротилася із 462 од. до 348 од., або на $24,68 \%$, а членів ВАКС - із 86 од. до 76 од., або на 11,63\%. Вартісні показники діяльності кредитних спілок зросли, проте ВАКС більшими темпами: депозитний портфель - 51,12\% проти 38,15\%, активів - 37,78\% проти 20,10\%, кредитного портфеля - 41,53\% проти $26,00 \%$, капіталу - $16,72 \%$ проти $5,91 \%$. 
Негативною ознакою $є$ відставання темпів зростання капіталу від інших вартісних показників, що свідчить про зменшення його достатності. Позитивною ознакою $є$ скорочення частки прострочених кредитів: по всім кредитним спілкам - із 20,5\% до 17,0\%, по членам ВАКС - із $16,6 \%$ до $12,4 \%$.

У 2019 р. членами кредитних спілок було 465,2 тис. осіб, у т.ч. $4,4 \%$ із них були вкладниками, 25,8\% - позичальниками. Членами кредитних спілок - учасників ВАКС $є$ 216,4 тис. фізичних осіб, з яких 60,4 тис. осіб (27,9\%) мають діючі кредитні договори; 12,8 тис. осіб (5,9\%) володіють залишками на депозитних рахунках, що сумарно складає третину. Тобто, участь переважної більшості членів КС (2/3 їх загального складу) є формальною.

Станом на 01.10.2019 р. кредити, надані членам кредитних спілок, становлять 2267,3 млн. грн., середній розмір кредиту на одного члена кредитної спілки, який має кредит, станом становить 18,9 тис. грн. Розподілення кредитів за інтервалами становить: до 10 тис. грн. $-15,7 \%$, від 10 до 30 тис. грн. $-40,1 \%$, від 30 до 50 тис. грн. - 7,6\%, від 50 до 100 тис. грн. $-17,8 \%$, від 100 до 500 тис. грн. $-11,9 \%$, більше 500 тис. грн. $-6,9 \%$.

Станом на 01.10.2019 р. основу кредитного портфеля кредитних спілок України становлять споживчі кредити (придбання автотранспорту, аудіотехніки, відео та побутової техніки, інші потреби) - 52,7\%\%, на другому місці знаходяться житлові кредити (будівництво, ремонт та реконструкція житла) та кредити особистим селянським господарствам - відповідно 19,4\% і 16,4\%. Третє місце розділяють такі види кредитів: комерційні кредити $-7,8 \%$, кредити фермерським господарствам $-3,7 \%$,

Станом на 01.10.2019 р. основу кредитного портфеля ВАСК становлять споживчі кредити (придбання побутової техніки, оплата навчання, весілля, відпочинок, лікування) $61 \%$, на другому місці знаходяться житлові кредити (будівництво, ремонт та реконструкція житла) - 21\%. Третє місце розділяють такі види кредитів: комерційні кредити $7 \%$, кредити фермерським господарствам $7 \%$, кредити особистим селянським господарствам - $4 \%$.

Основу кредитного портфелю кредитних спілок України та ВАКС становлять дов- гострокові кредити понад 12 місяців, на які приходиться відповідно 56,5\% і 58,8\%, та середньострокові - терміном від 3-х до 12-ти місяців (42,2\% і 40,7\%). Частка короткострокових кредитів (до 3 міс.) $є$ незначною відповідно 1,3\% і 0,5\%.

Прикладом фінансової нестійкості $\epsilon$ банкрутство наприкінці 2013 р. однієї 3 найбільших кредитних спілок в Луганській області «Айдар-кредит» (зареєстрованої у 2004 р.) [9]. Основна причина - махінації 3 фінансовою звітністю кредитної спілки, недостатній обсяг власного капіталу, вади наглядової діяльності 3 боку Національної комісії, що здійснює державне регулювання у сфері ринків фінансових послуг.

Протягом 2018-2019 pр. Нацкомфінпослуг здійснено ряд заходів, оріснтованих на удосконалення пруденційного регулювання кредитних спілок в частині: посилення вимог до платоспроможності кредитних спілок, обмеження їх ризиків під час здійснення операцій із фінансовими активами, затвердження методики розрахунку загальної вартості кредиту для споживача, реальної річної процентної ставки за споживчим кредитуванням, удосконалення правил здійснення депозитних операцій i методики оцінки кредитоспроможності позичальників, розробки плану відновлення фінансової стабільності кредитних спілок, встановлення вимог до формування резервів за операціями із фінансовими активами відповідно до міжнародних стандартів фінансової звітності [10]. 31 липня 2020 року кредитні спілки переходять у сферу регулювання НБУ у зв'язку з прийняттям так званого Закону про «спліт» [11] (англ. split - розділення), який передбачає ліквідацію Нацкомфінпослуг та розподіл повноважень 3 регулювання фінансового ринку між НБУ та Національною комісією 3 цінних паперів та фондового ринку.

При визначенні доцільності отримання кредитних коштів, потенційний клієнт оцінює свою спроможність розрахуватися за кредитом та не залишитися у збитках. Тому, найчастіше, віддає перевагу банківському кредитуванню перед кредитуванням 3 кредитної спілки, бо вважає відсотки за кредитом останньої занадто високими [12]. Однією 3 найважливіших причин, які гальмують кредитування у кредитних спілках $\epsilon$ високий рівень відсотків за кредитами (рисунок 1). 


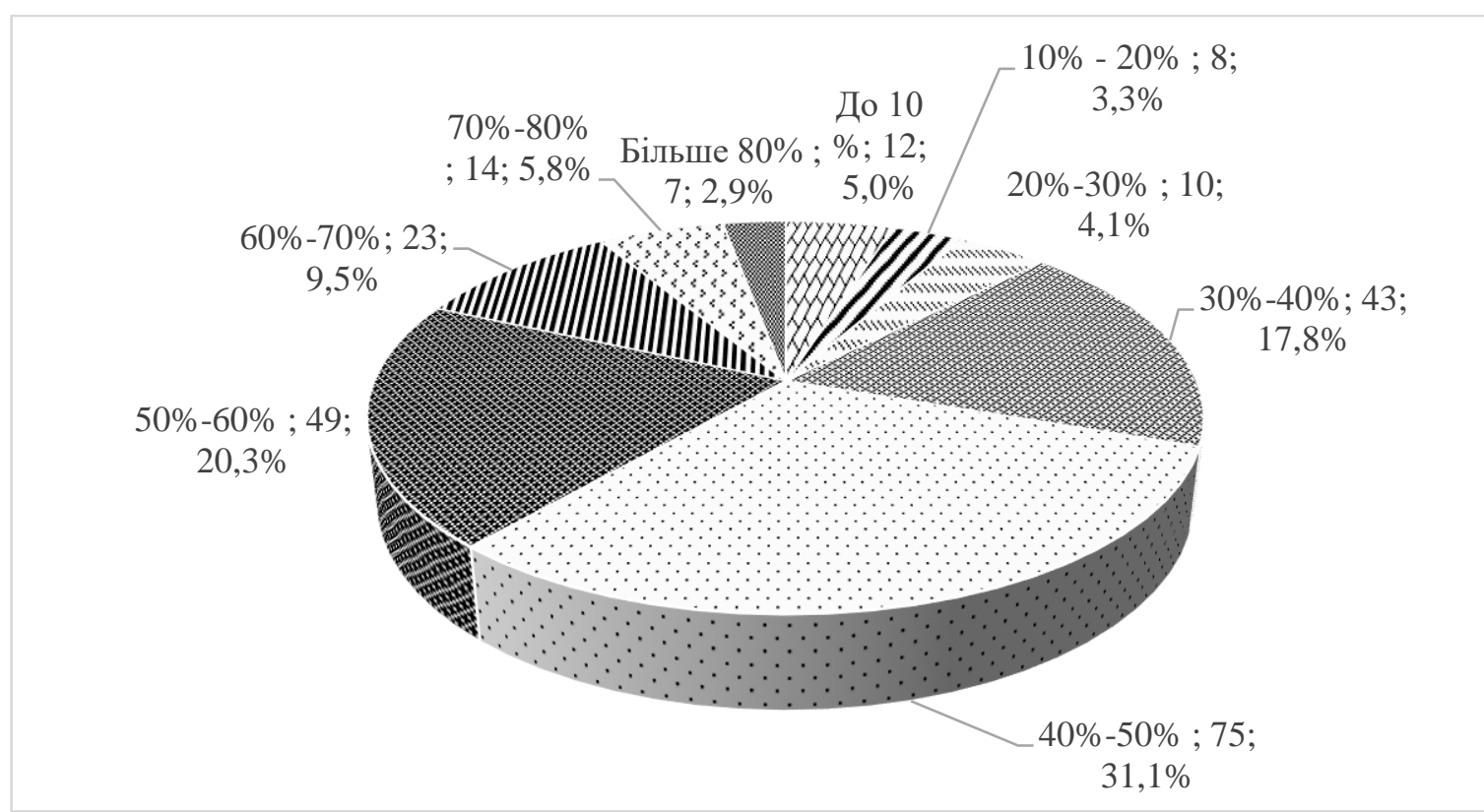

Рисунок 1 - Розподіл кредитних спілок за середньозваженими відсотковими ставками, 01.10.2019 p.

Джерело: розроблено авторами на підставі [7]

Середньозважені відсоткові ставки за кредитами кредитних спілок України значно варіюють. У майже третини підприємств $(31,1 \%)$ вони знаходяться в інтервалі $40 \%$ $50 \%$, у значної кількості підприємств $(20,3 \%)$ вони є більш високими і знаходяться в інтервалі 50\%-60\%. Меншими вони є у 43 кредитних спілках $(17,8 \%)$ і знаходяться в інтервалі $30 \%-40 \%$. Найменші відсоткові ставки (до $10 \%)$, за якими здійснюється процес кредитування, мають 12 кредитних спілок $(5,0 \%)$, найбільші (вище 80\%) - 7 кредитних спілок $(2,9 \%)$.

Зростання фінансового потенціалу суб'єктів господарювання аграрного сектора економіки забезпечуватиме розвиток маркетингової діяльності кредитних спілок: адаптація депозитних програм до умов незначних за розміром вкладів селян; пропозиція спеціальних кредитних продуктів, які відповідають вимогам ведення бізнесу у сільській місцевості; розробка процедур експертизи бізнес-планів, моніторингу стану використання і повернення позик; проведення активної інформаційно-роз'яснювальної роботи серед сільського населення, у т.ч. із залученням дорадчих служб, місцевих органів самоврядування [13].

Зміцненню фінансової стійкості кредитних спілок сприятиме впровадження скорингових механізмів в оцінку кредитоспроможності селян, які у стислі терміни дозволять зробити висновки про імовірність дефолту позичальників, перспективи розвитку їх бізнес-проектів, побудувати прогноз грошових потоків із погашення кредиту [14, с. 101]. Розвитку кооперативного кредитного руху на селі сприятиме координація діяльності кредитних спілок під егідою Національної асоціації кредитних спілок України, створення єдиної моделі автоматизованої системи кредитного скорингу і централізованої бази даних на кшталт Бюро кредитних історій, що сприятиме зменшенню ризиків в системі кредитної кооперації і забезпечуватиме легший доступ до отримання кредитів для платоспроможних позичальників - дрібних сільськогосподарських товаровиробників.

Висновки та перспективи подальших досліджень. 1. Кредитні спілки в Україні мають статус неприбуткових установ і активно розвиваються протягом двадцятирічного періоду у зв'язку з прийняттям відповідного законодавства. Проте реалізацію їх фінансового потенціалу стримує юридична невизначеність засад діяльності як кооперативної організації, а також недоліки пруденційного регулювання. Прийняття законодавства про «спліт», посилення вимог до платоспроможності та достатності капіталу кредитних спілок матиме позитивний вплив на їх діяльність.

2. Вадами розвитку системи кредитних спілок є: нерівномірна дислокація за регіона- 
ми; невелика кількість членів, а також їх частка, яка має реальні депозити (кредити); недостатній обсяг фінансових ресурсів, який не дозволяє задовольнити попит сільськогосподарських товаровиробників на кредити, значна диференціація обсягів кредитів і рівня процентних ставок за ними, фінансова нестійкість.

3. Перевагами кредитних спілок для малих форм агробізнесу є: представництво в регіонах із розвинутим сільськогосподарським виробництвом, територіальна доступність, можливість для особистих підсобних і фермерських господарств отримати невеликі за розміром суми кредиту на тривалий термін. Стратегічний потенціал розвитку кредитних спілок пов'язаний із підтримкою не лише поточної діяльності особистих селянських та фермерських господарств, але і з фінансуванням інноваційно-інвестиційних проектів.

Метою подальших досліджень $\epsilon$ обгрунтування механізмів банківського фінансування стратегічного розвитку суб'єктів господарювання аграрного сектора економіки.

\section{Список літератури:}

1. Добровольська О. В. Сучасний стан та проблеми розвитку кредитних спілок в аграрній сфері України. Науковий вісник Херсонського державного університету. Сер.: Економічні науки. 2015. Вип. 11(2). С. 104107.

2. Про кредитні спілки: Закон України від 20.12.2001 № 2908-III. URL: https://zakon.rada.gov.ua/laws/show/2908-14 (дата звернення : 10.01.2020р.)

3. Катан Л. І., Косюга В. В., Добровольська О. В. Економічна сутність кредитної спілки як особливої форми сільськогосподарської кредитної кооперації. Вісник Дніпропетровського державного аграрноекономічного університету. 2015. № 1. С. 610.

4. Клименко В. І., Кібенко К. С. Забезпечення інноваційного розвитку аграрного сектора національної економіки на основі потенціалу кредитних спілок. Науковий вісник Полтавського університету економіки $i$ торгівлі. Сер. : Економічні науки. 2013. № 4. C. 39-44.

5. Орлов О. В. Участь кредитних спілок у розвитку зеленого туризму - вагомий фактор відродження сільських громад. Науковий вісник Полтавського університету економіки $i$ торгівлі. Серія : Економічні науки. 2016. № 2. С. 84-91.

6. Крот Л. М. Кредитні спілки як джерело фінансування підприємств аграрного сектора економіки. Агросвіт. 2013. № 7. С. 79-84.

7. Підсумки діяльності кредитних спілок 2016-2019. URL: https://www.nfp.gov.ua (дата звернення : 11.01.2020 p.)

8. Зведені дані кредитних спілокчленів Всеукраїнської асоціації кредитних спілок 2016-2019. URL: http://www.vaks.org.ua (дата звернення : 12.01.2020 p.)

9. Крупный луганский кредитный союз «Айдар-кредит» не может рассчитаться с вкладчиками. Мінфін. 25 грудня 2013. URL: https://minfin.com.ua/ua/2013/12/51859/ (дата звернення : 08.01.2020р.)

10. Річний звіт Нацкомфінпослуг, за 2018 рік. URL: https://www.nfp.gov.ua/files/ (дата звернення : 09.01.2020 p.)f

11. Про внесення змін до деяких законодавчих актів України щодо удосконалення функцій із державного регулювання ринків фінансових послуг: Закон України від 12.09.2019 № 79-IX. URL: https://zakon.rada.gov.ua/laws/show/79 (дата звернення : 10.01.2020 p.)

12. Соломатіна Т.В. Оптимізація відсоткової ставки за кредитами у кредитних спілках. Науковий вісник Луганського національного аграрного університету : Економічні науки : зб. наук. пр. / Луган. нац. агpap. ун-т. - Луганськ: Елтон-2, 2010. Вип. 10. C. 270-274.

13. Левандовська А. В. Кредитні спілки та їх роль у фінансовому забезпеченні сільськогосподарського виробництва України. Вісник Східноєвропейського університету економіки і менеджменту. Серія : Економіка і менеджмент. 2008. № 1. С. 5968.

14. Орлов О. В. Мінімізація кредитних ризиків у діяльності сільських кредитних спілок із використанням систем скорингу. Вісник Полтавської державної аграрної академії. 2015. № 4. С. 99-102.

\section{References}

1. Dobrovolska, O. V. (2015). The current state of the problem and development of credit loans in the agricultural sector of Ukraine. 
Scientific Bulletin of the Poltava University of Eco nomics and Trade, 11(2), 104-107.

2. About credit unions (Law of Ukraine No. 2908-III of 20.12.2001). Retrieved from: https://zakon.rada.gov.ua/laws/show/2908-14 (accessed 01 March 2019). (in Ukrainian)

3. Katan, L. I. \& Kosiuha, V. V. \& Dobrovolska, O. V. (2015). Economic essence of the credit union as a special form of agricultural credit cooperation. Scientific Bulletin of Poltava University of Economics and Trade, 1, 6-10.

4. Klymenko, V. I. \& Kibenko, K. S. (2013). Ensuring innovative development of the agricultural sector of the national economy based on the potential of credit unions. Scientific Bulletin of Poltava University of Economics and Trade, 4, 39-44.

5. Orlov, $O . V$. (2016). The involvement of credit unions in the development of green tourism is a significant factor in the revival of rural communities. Scientific Bulletin of Poltava University of Economics and Trade, 2, 84-91.

6. Krot, L. M. (2013). Credit unions as a source of financing for agricultural enterprises. Agro-world, 7, 79-84.

7. Summary of the activities of credit unions (2016-2019). Retrieved from: https://www.nfp.gov.ua (accessed 01 March 2019).

8. Summary data of credit unionsmembers of All-Ukrainian Association of Credit Unions (2016-2019). Retrieved from:

Стаття надійшла

до редакції : 18.01.2020 p. http://www.vaks.org.ua (accessed 01 March 2019).

9. The large Lugansk credit union "Aidar-credit" cannot pay off its depositors (2013). Minfin. Retrieved from: https://minfin.com.ua/en/2013/12/25/851859/ (accessed 01 March 2019).

10. Annual report of the National Commission, which is sovereign to regulate the sphere of financial services (2018). Retrieved from: https://www.nfp.gov.ua/files/ (accessed 01 March 2019).

11. On Amendments to Some Legislative Acts of Ukraine Regarding Improvement of Functions in State Regulation of Financial Services Markets (Law of Ukraine No. 79-IX of 12.09.2019). Retrieved from: https://zakon.rada.gov.ua/laws/show/7

12. Solomatina, T. V. (2010). Optimization of the interest rate on loans in credit unions. Bulletin of the Lugansk National Agrarian University. Scientific Bulletin of Lugansk National Agrarian University, 10, 270-274.

13. Levandovska, A. V. (2008). Credit unions and their role in financial support of agricultural production in Ukraine. Bulletin of the Eastern European University of Economics and Management. Series: Economics and Management, 1, 59-68.

14. Orlov, O. V. (2015). Minimizing credit risk in rural credit unions using scoring systems. Bulletin of Poltava State Agrarian Academy, 4, 99-102.

Стаття прийнята

до друку: 27.02.2020 p.

\section{Бібліографічний опис для цитування :}

Костирко Л. А. Фінансовий потенціал кредитних спілок у системі розвитку малих форм агробізнесу / Л. А. Костирко, Т. В. Соломатіна // Часопис економічних реформ. - 2020. - № 1 (37). - С. $57-64$. 